\title{
Power, Conflict and the Environment: Recent Literature
}

\author{
Barry S. Levitt
}

In the late twentieth century, we have finally come to realize that environmental issues are central to the forces that generate many Third World civil wars, ethnic conflicts and refugee flows. Yet, few detailed studies have been carried out to clarify the relationship between social and economic power, conflict and the environment.

One recent work which provides such detailed insight is Environment Under Fire, by Daniel Faber (1993). Faber, a Professor of Sociology at Northeastern University in Boston, was a founder of both the Environmental Project on Central America (EPOCA) and the international journal Capitalism, Nature, Socialism. His latest writing effectively broadens the perception of the economic crisis and social conflict facing Central America today, to include both social and environmental aspects.

Faber emphasizes a historical perspective, in which colonialism is defined to include the colonization of nature. After the colonial period in Central America, U.S. hegemony and capitalist development each continued to facilitate the joint exploitation of natural resources and human beings. Faber characterizes the region as embodying a "functional dualism," in that a small but wealthy sector, in concert with multinational capital, benefits from the extractive and agro-export industries, which in turn depends upon an underdeveloped subsistence sector to provide an enormous "reserve army" of semi-proletariat labour.

Dualism, and the enormous power differential between social classes that it perpetuates, has allowed the development process to unload the environmental costs of production onto the politically and economically weak.

Barry Levitt is a graduate student in the Department of Political Science, York University.
Monocultures over extensive tracts of land reduces soil fertility, and changes rain and drainage patterns. Most importantly, large, mechanized farms dislocate labour to hillsides and marginal lands. Clearing the forest and farming these lands may lead to severe environmental damage, particulariy through erosion of hillsides. Social conflict is widespread under these circumstances. Poor farmers who flee such a precarious existence are both "ecological refugees" and "social refugees." As the ecological basis for small and intermediate farms, and their diversified production are undermined, rural communities disintegrate, and large numbers of people are forced to move.

Faber focuses, in particular, on the cotton and beef industries, two sectors which are typical of the destructive export-oriented development of Central America. Cotton production has required the increasing use of powerful chemical pesticides, often with complete disregard for the health of agricultural workers and surrounding communities, as well as to the eventual consumers of these agricultural products. Similarly, cattle production is a major contributor to the appalling deforestation of Central America. This environmental degradation, coupled with the forced eviction of peasants to make room for cattle grazing lands, has contributed to the region's refugee problem.

Further exacerbating the plight of "ecological refugees" is the damage caused by civil war and the militarization of society. Faber vehemently denounces the role of the U.S. in causing and exacerbating military conflict in the region, and addresses the multiple social effects of these practices, such as rapid urbanization, social displacement, and the exploitation of women and child labour. As well, he conveys a sense of the damage to the physical environment caused by "scorched earth" military campaigns (e.g., Guatemala), large scale bombings involving the use of napalm and white phosphorous (e.g., El Salvador), strategic deforestation and forced resettlement. All of these have significant consequences in terms of human migration.

The author contrasts these practices with those of a regime which he believes placed a significant emphasis on environmental issues; the FSLN (Sandinista) government of Nicaragua, in power between 1979 and 1990. Faber admits the mistakes of the FSLN (e.g., early attempts at land reform which created large state farms and displaced existing communities), but focuses mostly on their environmental successes. These policies alleviated at least a part of the social dislocation caused by the revolutionary upheaval and the U.S.-backed Contras.

Faber concludes his book with an analysis of the relationship between U.S. prosperity (both historical and contemporary) and the "externalization" of the cost of environmental degradation arising from this prosperity onto Central America. He argues that economic globalization and liberalization in general, and structural adjustment programs in particular, are further exacerbating the environmental damage of the Central American region (and implicitly increasing the number of "environmental refugees"). As such, the issue of power within the international system must be central to an understanding of the crises faced by the peoples of Central America.

The value of Faber's analysis becomes even more apparent when compared to other recent writings on this topic. For example, the February 1993 issue of Scientific American featured an article entitled "Environmental Change and Violent Conflict," coauthored by T.F. Homer-Dixon and the other directors of the Project on Environmental Change and Acute Conflict, 